\title{
Renal amino acid, fat and glucose metabolism in type 1 diabetic and non-diabetic humans: effects of acute insulin withdrawal
}

Received: 4 January 2006 / Accepted: 12 March 2006 / Published online: 23 May 2006

C) Springer-Verlag 2006

\begin{abstract}
Aims/hypothesis: The aim of this study was to test the hypothesis that type 1 diabetes alters renal amino acid, glucose and fatty acid metabolism. Materials and methods: We studied five C-peptide-negative, type 1 diabetic subjects during insulin replacement (glucose $5.6 \mathrm{mmol} / \mathrm{l}$ ) and insulin deprivation (glucose $15.5 \mathrm{mmol} / \mathrm{l}$ ) and compared them with six non-diabetic subjects. Leucine, phenylalanine, tyrosine, glucose and palmitate tracers were infused after an overnight fast and samples were obtained from the renal vein, femoral vein and femoral artery. Results: Insulin deprivation significantly increased wholebody fluxes $(20-25 \%)$ of phenylalanine, tyrosine and leucine, and leucine oxidation (50\%). Kidney contributed $5-10 \%$ to the whole-body leucine and phenylalanine flux. A net uptake of phenylalanine, conversion of phenylalanine to tyrosine $(5 \mu \mathrm{mol} / \mathrm{min})$ and net release of tyrosine $(\sim 5 \mu \mathrm{mol} / \mathrm{min})$ occurred across the kidney. Whole-body (three-fold) and leg (two-fold) leucine transamination increased but amino acid metabolism in the kidney did not alter with diabetes or insulin deprivation. Insulin deprivation doubled endogenous glucose production, renal glucose production was unaltered by insulin deprivation and diabetes (ranging between 100 and $140 \mu \mathrm{mol} / \mathrm{min}$ ).
\end{abstract}

N. Moller · M. D. Jensen · R. A. Rizza · K. S. Nair $(\bowtie)$

Endocrine Research Unit, Mayo Clinic College of Medicine, 200 First Street SW, 5-194 Joseph,

Rochester, MN 55905, USA

e-mail: nair@mayo.edu

Tel.: +1-507-2552415

Fax: $+1-507-2554828$

N. Moller

Medical Department M (Diabetes and Endocrinology),

Aarhus University Hospital,

Aarhus C, Denmark

\section{J. C. Andrews}

Vascular and Interventional Radiology,

Mayo Clinic College of Medicine,

200 First Street SW, 5-194 Joseph,

Rochester, MN 55905, USA
Renal palmitate exchange was unaltered by insulin deprivation. Conclusions/interpretation: In conclusion, kidney postabsorptively accounts for $5-10 \%$ of whole-body protein turnover, $15-20 \%$ of leucine transamination and $10-15 \%$ of endogenous glucose production, and actively converts phenylalanine to tyrosine. During insulin deprivation, leg becomes a major site for leucine transamination but insulin deprivation does not affect renal phenylalanine, leucine, palmitate or glucose metabolism. Despite its key metabolic role, insulin deprivation in type 1 diabetic patients does not alter many of these metabolic functions.

Keywords Arteriovenous kidney and leg technique . Glucose · Indirect calorimetry · Leucine $\cdot$ Palmitate · Tracers

Abbreviations KIC: ketoisocaproate $\cdot \mathrm{PAH}$ : paraaminohippurate

\section{Introduction}

In people with type 1 diabetes, lack of insulin has a profound effect on intermediary metabolism. Insulin deprivation increases production of glucose and lipid intermediates [1], accelerates proteolysis [2, 3] and alters substrate disposal. This results in high plasma concentration levels of NEFA, ketone bodies and increased circulating concentrations of most amino acids [1-3]. Until recently it was assumed that the primary tissues participating in these events were liver (increased glucose production and ketogenesis), adipose tissue (increased lipolysis) and muscle (increased proteolysis) [1-3]. Several reports have suggested that in addition the kidney may be an important component in the regulation of intermediary metabolism, in particular glucose metabolism [4]. This renewed interest in the metabolic role of the kidney was fuelled by a study by Cersosimo et al. [5] who used arteriovenous balance and isotopic dilution techniques to report that in postabsorptive dogs renal glucose utilisation and production each accounted for close to $30 \%$ of total glucose turnover in 
the presence of net balances close to zero. More recent studies in humans have reported that the renal contribution to postabsorptive whole-body glucose production may amount to between 15 and $30 \%$, that glutamine appears to be an important precursor for renal gluconeogenesis and that renal glucose production increases in response to epinephrine and hypoglycaemia and decreases during insulin exposure [6-11]. Other investigators, however, have failed to show any significant renal contribution to overall endogenous glucose production [12].

It is well established that insulin deprivation leads to high protein turnover with disproportionately increased protein degradation $[2,3]$. Analysis of regional protein turnover by means of catheterisation has revealed that the increase in protein synthesis almost exclusively occurs in the splanchnic bed, whereas the excessive protein breakdown is most pronounced in muscle [3]. It was additionally found that deamination of leucine to ketoisocaproate (KIC) and reamination of KIC to leucine was increased five-fold during insulin deprivation, but the tissues responsible for this phenomenon were not identified. A recent report used renal vein catheterisation and radioactive amino acid tracers and demonstrated that in non-diabetic postabsorptive humans $25 \%$ of leucine oxidation and around $10 \%$ of leucine appearance and leucine protein synthesis took place in the kidney [13]. The kidney has also been shown to be a major site of phenylalanine conversion to tyrosine and a contributor of tyrosine to the circulation [14].

Little information is available about the role of the kidney in lipid metabolism. One previous report has found that the main oxidative fuels extracted by the kidney in the postabsorptive state were lactate and free fatty acids [15], but these results could not be confirmed in insulin-depleted diabetic patients [16].

The present study was therefore undertaken to define the role of the kidney in intermediary metabolism with particular reference to alterations of amino acid, fat, and glucose metabolism following acute insulin withdrawal. To answer these questions we studied five type 1 diabetic subjects during insulin replacement and insulin deprivation and compared the results to those observed in six healthy non-diabetic control subjects. Renal glucose, amino acids and palmitate production and uptake, as well as phenylalanine conversion to tyrosine, by the kidney were measured using the renal catherisation and tracer dilution method.

\section{Research design and methods}

\section{Subjects}

Six type 1 diabetic patients were recruited for the study. Problems with maintenance of correct catheter placement caused one patient to be excluded. Hence five C-peptidenegative, diabetic subjects (two male and three female, age $30.4 \pm 2.9$ years, diabetes duration $12.4 \pm 2.0$ years, insulin dose $46.4 \pm 5.9 \mathrm{IU} /$ day, BMI between 28 and $19 \mathrm{~kg} / \mathrm{m}^{2}, \mathrm{HbA}_{1 \mathrm{c}} 8.5 \pm$ $0.2 \%$ ) were each studied twice and six healthy control subjects (three female, three male, age $30.7 \pm 2.0$ years, BMI between 28 and $19 \mathrm{~kg} / \mathrm{m}^{2}$ ) were each studied once. One patient from the diabetic group and one patient from the control group were on stable L-thyroxine replacement therapy because of hypothyroidism. Otherwise none received any medication. Two of the diabetic subjects had mild background retinopathy. None had microalbuminuria, hypertension or signs or symptoms of neuropathy or macroangiopathy. Studies in the diabetic subjects were separated by a minimum of 2 months. Women participating in the study were examined during the luteal phase of the menstrual cycle. Before the study the protocol was submitted to and approved by the Mayo Institutional Review Board and the purpose and potential risks of the study were explained to all subjects and informed, written consent was obtained from all of them.

\section{Analysis of samples}

$\mathrm{L}-\left[{ }^{15} \mathrm{~N}\right]$ phenylalanine (99 atom\% excess) and L- $\left[1-{ }^{13} \mathrm{C},{ }^{15} \mathrm{~N}\right]$ leucine (99 atom\% excess) were purchased from Cambridge Isotope Laboratories (Andover, MA, USA) and $\mathrm{L}-\left[\right.$ ring- $\left.{ }^{2} \mathrm{H}_{4}\right]$ tyrosine (99 atom\% excess) and $\mathrm{L}-\left[{ }^{15} \mathrm{~N}\right]$ tyrosine (99 atom\% excess) were purchased from Isotec (Maimisburgh, $\mathrm{OH}, \mathrm{USA}) \cdot\left[6,6-{ }^{2} \mathrm{H}_{2}\right]$ glucose $\left({ }^{2} \mathrm{H}, 99\right.$ atom $\%$ ) was purchased from Cambridge Isotope Laboratories.

The chemical, isotopic and optical purity of these compounds was confirmed before use. Solutions were prepared under sterile conditions in the pharmacy and were shown to be free of bacteria and pyrogens before administration.

$\left[9,10-{ }^{3} \mathrm{H}\right]$ palmitate was obtained from NEN Research Products (Wilmington, DE, USA). Cardiogreen (indocyanine) was purchased from Becton Dickinson (Cockeysville, $\mathrm{MD}, \mathrm{USA}$ ) and paraaminohippurate (PAH) was obtained from Merck (West Point, PA, USA).

\section{Study protocol}

Type 1 diabetic patients were treated with 6-hourly regular insulin for 3 days before the study and their longacting insulins were discontinued to avoid a carryover effect of insulin during the metabolic study. All subjects ingested a standardised weight-maintaining diet for 3 days before the study. The diabetic patients were studied on two separate occasions - during insulin deprivation and during insulin treatment. On each occasion subjects were admitted to the clinical research centre at $17.00 \mathrm{~h}$ the evening before the study and, following ingestion of a standard meal, kept fasted until the end of the study. Diabetic subjects received their last injection of slowly acting insulin $72 \mathrm{~h}$ before the study and the last subcutaneous injection of regular insulin $12 \mathrm{~h}$ before the study. After catheterisation of an antecubital vein, infusion of either insulin (to keep plasma glucose between 4.5 and $6.5 \mathrm{mmol} / \mathrm{l}$ ) or saline was commenced at $24.00 \mathrm{~h}$ and continued throughout the study. The nondiabetic subjects received saline. Glucose concentrations were monitored throughout the night. Between 07.30 and 
$08.30 \mathrm{~h}$ the following morning cannulas were placed in the femoral vein, one renal vein and the femoral artery, as described previously $[6,13,16,17]$. Renal vein catheters were inserted under fluoroscopic guidance; the femoral artery line was used for infusion of indocyanine green $(0.6 \mathrm{mg} / \mathrm{min})$ to measure blood flow in the leg and for blood sampling. Femoral vein and renal vein catheters were used to collect blood samples. The peripheral antebrachial vein was used for infusion of isotopes, insulin and PAH.

After taking duplicate baseline samples, priming doses followed by continuous infusion of $\left[{ }^{15} \mathrm{~N}, 1-{ }^{13} \mathrm{C}\right]$ leucine $\left(1 \mathrm{mg} / \mathrm{kg}\right.$ and $\left.1 \mathrm{mg} \mathrm{kg}^{-1} \mathrm{~h}^{-1}\right),\left[{ }^{15} \mathrm{~N}\right]$ phenylalanine $\left(0.75 \mathrm{mg} / \mathrm{kg}\right.$ and $\left.0.75 \mathrm{mg} \mathrm{kg}{ }^{-1} \mathrm{~h}^{-1}\right),\left[{ }^{2} \mathrm{H}_{4}\right]$ tyrosine $\left(0.6 \mathrm{mg} / \mathrm{kg}\right.$ and $\left.0.6 \mathrm{mg} \mathrm{kg}^{-1} \mathrm{~h}^{-1}\right)$ and $\left[6,6{ }^{2} \mathrm{H}_{2}\right]$ glucose $\left(2.4 \mathrm{mg} / \mathrm{kg}\right.$ and $\left.2.4 \mathrm{mg} \mathrm{kg}^{-9} \mathrm{~h}^{-1}\right)$, together with a priming dose of $\left[{ }^{13} \mathrm{C}\right]$ sodium bicarbonate $(0.2 \mathrm{mg} / \mathrm{kg})$ and $\left[{ }^{15} \mathrm{~N}\right]$ tyrosine $(0.3 \mathrm{mg} / \mathrm{kg})$ were given at $08.00 \mathrm{~h}$. Infusions were continued for $4 \mathrm{~h}$ in all cases. At $11.00 \mathrm{~h}$ a 1 -h infusion of $\left[{ }^{3} \mathrm{H}\right]$ palmitate $(11.1 \mathrm{kBq} / \mathrm{min})$ was administered for determination of palmitate turnover. Cardiogreen was infused at a rate of $0.6 \mathrm{mg} / \mathrm{min}$ from $10.30 \mathrm{~h}$ for $90 \mathrm{~min}$. PAH was given as a 3-mmol bolus followed by a constant infusion of $0.1 \mathrm{mmol} / \mathrm{min}$ for three sequential clearance periods from $10.30 \mathrm{~h}$ onwards $[8,11,12]$.

Urine was collected over the entire 240-min study period in two portions $(0-120$ and $120-240 \mathrm{~min})$. A total minimum water input (i.v. + oral) of $250 \mathrm{ml} / \mathrm{h}$ was maintained throughout the 4-h study period. Indirect calorimetry was performed from 10.30 to $11.00 \mathrm{~h}$. Duplicate blood and breath samples were collected from $07.45-08.00 \mathrm{~h}$ and every $15 \mathrm{~min}$ from $11.00-12.00 \mathrm{~h}$.

Blood glucose was measured by a glucose oxidase method (Beckman Instruments, Fullerton, CA, USA). Lactate, 3-hydroxybutyrate and NEFA were analysed as described previously [3], as was circulating epinephrine [18]. Plasma insulin and growth hormone were measured using a chemiluminescent sandwich assay (Sanofi Diagnostics, Chaska, MN, USA) and glucagon and cortisol were measured with radioimmunoassays (Diagnostic Products, Los Angeles, CA, USA). Indocyanine green concentrations were measured by spectrophotometry and PAH was measured calorimetrically.

Plasma enrichment levels of $\left[{ }^{15} \mathrm{~N}\right]$ phenylalanine, $\left[{ }^{2} \mathrm{H}_{4}\right]$ tyrosine, $\left[{ }^{15} \mathrm{~N}\right]$ tyrosine, $\left[1-{ }^{13} \mathrm{C},{ }^{15} \mathrm{~N}\right]$ leucine and $\left[1-{ }^{13} \mathrm{C}\right]$ leucine were determined by gas chromatography/mass spectrometry as described elsewhere $[3,14]$.

Isotopic enrichment of $\left[6,6-{ }^{2} \mathrm{H}_{2}\right]$ glucose was measured by gas chromatography/mass spectrometry (Hewlett Packard 5972 GC/MS, Palo Alto, CA, USA) using the trimethylsilyl$O$-methyloxime derivate and monitoring fragment ions at $\mathrm{m} / \mathrm{z} 321$ and 319, as described previously [19].

Plasma palmitate concentrations and specific activity were determined by HPLC with the use of $\left[{ }^{2} \mathrm{H}_{31}\right]$ palmitate as internal standard [20]. Palmitate concentrations in the insulin-withdrawn state were sufficiently high that it was necessary to calculate concentration and measure the palmitate content (nmol) in these samples using curvilinear formulae $\left(R^{2}>0.99\right.$ for standard curves).

\section{Calculations}

Plasma flows (PFs) from the kidney were calculated as outlined previously [16] and converted to blood flows (BFs) using the equation:

$$
\mathrm{BF}=\mathrm{PF} /(1-\text { haematocrit }) \text {. }
$$

An isotopic plateau was observed from 180-240 min in all cases. This was assessed based on the observation that when isotopic enrichment values (or specific activity) of the tracers utilised in different sites were plotted against time the ensuing slopes were not different from zero. Mean values for any isotope at each plateau were used for all calculations of substrate kinetics.

Whole-body phenylalanine flux $\left(Q_{\mathrm{Phe}}\right)$ was calculated as follows:

$Q_{\mathrm{Phe}}=i_{\mathrm{Phe}} \times\left(\left[i_{\mathrm{ePhe}} / P_{\mathrm{ePhe}}\right]-1\right)$

where $i_{\text {Phe }}$ is the rate of phenylalanine infusion $\left(\mu \mathrm{mol} \mathrm{kg}{ }^{-1}\right.$ body weight $\left.\mathrm{min}^{-1}\right), i_{\mathrm{ePhe}}$ is the isotopic enrichment of the infusate and $P_{\mathrm{ePhe}}$ is $\left[{ }^{15} \mathrm{~N}\right]$ phenylalanine enrichment at isotopic plateau. Similar calculations were performed for $\left[{ }^{2} \mathrm{H}_{4}\right]$ tyrosine $\left(Q_{\mathrm{Tyr}}\right)$.

Conversion to tyrosine is the initial step in phenylalanine degradation and whole-body phenylalanine-to-tyrosine $\left(I_{\mathrm{PT}}\right)$ conversion was calculated using the equation:

$$
\begin{aligned}
I_{\mathrm{PT}}= & Q_{\mathrm{Tyr}} \times\left(\left[{ }^{15} \mathrm{~N}\right] P_{\mathrm{Tyr}} /\left[{ }^{15} \mathrm{~N}\right] P_{\mathrm{Phe}}\right) \\
& \times\left(Q_{\mathrm{Phe}} /\left[I_{\mathrm{Phe}}+Q_{\mathrm{Phe}}\right]\right)
\end{aligned}
$$

where $\left[{ }^{15} \mathrm{~N}\right] P_{\text {Tyr }}$ and $\left[{ }^{15} \mathrm{~N}\right] P_{\text {Phe }}$ are steady-state isotopic enrichments of tyrosine and phenylalanine, respectively.

Whole-body incorporation of phenylalanine into protein is calculated by subtracting $I_{\mathrm{PT}}$ from $Q_{\mathrm{Phe}}$ because apart from conversion to tyrosine the only other fate of phenylanine is protein synthesis. The basis of these equations is discussed elsewhere $[3,21]$.

Regional dynamics of phenylalanine, tyrosine and leucine

Net amino acid balances across organs were calculated by multiplying arteriovenous differences by blood flows. For calculation of across-organ isotope kinetics we used the equations described previously $[3,14]$. 
The rate of appearance of phenylalanine $\left(R_{\mathrm{a}(\mathrm{Phe})}\right)$, representing local protein breakdown was determined as follows:

$\left.R_{a(P h e)}=\left\{\left(\left[{ }^{15} \mathrm{~N}\right] \mathrm{Phe}_{\mathrm{EA}} /\left[{ }^{15} \mathrm{~N}\right] \mathrm{Phe}_{\mathrm{EV}}\right)-1\right)\right\} \times \mathrm{Phe}_{a} \times \mathrm{BF}$

where $\left[{ }^{15} \mathrm{~N}\right] \mathrm{Phe}_{\mathrm{EA}}$ and $\left[{ }^{15} \mathrm{~N}\right] \mathrm{Phe}_{\mathrm{EV}}$ are enrichments in artery and vein, $\mathrm{Phe}_{\mathrm{a}}$ is arterial concentration of phenylalanine and $\mathrm{BF}$ is the blood flow. Rate of appearance of tyrosine was calculated similarly.

Local conversion of phenylalanine-to-tyrosine $\left(I_{\mathrm{PT}}\right)$ was calculated by:

$I_{\mathrm{PT}}=\left\{\begin{array}{r}\left(\left[{ }^{2} \mathrm{H}_{4}\right] \mathrm{Tyr}_{\mathrm{EA}} /\left[{ }^{2} \mathrm{H}_{4}\right] \mathrm{Tyr}_{\mathrm{EV}}\right) \\ \times\left(\left[{ }^{15} \mathrm{~N}\right] \mathrm{Tyr}_{\mathrm{EV}} /\left[{ }^{15} \mathrm{~N}\right] \mathrm{Phe}_{\mathrm{EV}}\right) \\ -\left(\left[{ }^{15} \mathrm{~N}\right] \mathrm{Tyr}_{\mathrm{EA}} /\left[{ }^{15} \mathrm{~N}\right] \mathrm{Phe}_{\mathrm{EV}}\right)\end{array}\right\} \times \mathrm{Tyr}_{a} \times \mathrm{BF}$

Calculations of local phenylalanine incorporation into protein can now be determined after calculation of phenylalanine rate of disappearance $\left(\mathrm{Rd}_{(\mathrm{Phe})}\right)$

$R_{d(\mathrm{Phe})}=R_{a(\mathrm{Phe})}+\left(\mathrm{Phe}_{\mathrm{A}}-\mathrm{Phe}_{\mathrm{E}}\right) \times \mathrm{BF}$

Leucine kinetics, leucine appearance rate from protein and leucine transamination were measured using the equations previously described by Cheng et al. [3, 22]. Leucine oxidation rates were measured using $\left[{ }^{13} \mathrm{C}\right] \mathrm{KIC}$ as the precursor pool [3] and protein synthesis (disappearance) rates were determined as the sum of net balances and calculated breakdown (appearance) rates.

Whole-body rate of appearance (Ra) for glucose was calculated by dividing the rate of infusion of labelled glucose by enrichment.

Net renal glucose exchange was calculated as the product of arteriovenous plasma glucose concentration differences and renal blood flow.
Regional renal production of glucose was in all circumstances calculated using the simple equation $[12,23]$ :

$R_{a(\text { renal })}=\mathrm{BF} \times[\text { glucose }]_{\mathrm{art}} \times\left(E_{\mathrm{art}} / E_{\mathrm{ven}}-1\right)$

in which $R_{\mathrm{a}}$ is renal glucose production, $\mathrm{BF}$ is total renal blood flow, [glucose] $]_{\text {art }}$ is the arterial glucose concentration and $E_{\mathrm{ven}}$ and $E_{\text {art }}$ represent enrichment in venous or arterial blood. As pointed out earlier [12] the small size of the fractional extractions $(<3 \%)$ of glucose across the renal bed means that their contributions to the calculation become negligible. For that reason the parameter was omitted. Negative values for regional glucose production were included in the mean calculations.

Regional renal glucose uptake was determined as the sum of renal glucose production and net renal glucose exchange.

Systemic palmitate $R_{\mathrm{a}}$ and regional palmitate exchange were calculated as described previously [24], with the use of the measured tracer purity to determine the correct infusion rate.

\section{Statistics}

All values are given as mean \pm SEM. Paired and unpaired $t$-tests were used to assess whether any parameter differed significantly between the insulin-treated and insulindeprived states and between diabetic and non-diabetic subjects, respectively. A $p$ value $<0.05$ (two-tailed) was considered statistically significant.

\section{Results}

Blood flow, circulating substrates and hormones and indirect calorimetry

In all cases renal blood flow was stable at $\sim 11 \mathrm{ml} / \mathrm{min}$ and leg blood flow at $\sim 400-500 \mathrm{ml} / \mathrm{min}$ (Table 1). Plasma

Table 1 Blood flows, circulating substrates and hormones and calorimetric data in five diabetic subjects with and without insulin and in six control subjects

\begin{tabular}{lccc}
\hline & Insulin-treated diabetic patients & Insulin-deprived diabetic patients & Control subjects \\
\hline Renal blood flow (l/min) & $0.93 \pm 0.08$ & $0.99 \pm 0.10$ & $1.19 \pm 0.18$ \\
Leg blood flow(l/min) & $0.47 \pm 0.05$ & $0.39 \pm 0.03$ & $0.43 \pm 0.09$ \\
Plasma glucose (mmol/l) & $5.6 \pm 0.3$ & $15.5 \pm 2.0^{\mathrm{a}, \mathrm{b}}$ & $5.0 \pm 0.1$ \\
Plasma 3-hydroxybutyrate (mmol/l) & $0.59 \pm 0.02$ & $1.56 \pm 0.09^{\mathrm{a}, \mathrm{b}}$ & $0.50 \pm 0.06$ \\
Plasma lactate $(\mu \mathrm{mol} / \mathrm{l})$ & $0.76 \pm 0.16$ & $0.78 \pm 0.05$ & $0.58 \pm 0.03$ \\
Plasma insulin $(\mathrm{mU} / \mathrm{l})$ & $10.8 \pm 2.0$ & $1.5 \pm 0.7^{\mathrm{a}, \mathrm{b}}$ & $4.4 \pm 0.6$ \\
Plasma C-peptide $(\mathrm{pmol} / \mathrm{l})$ & $68 \pm 10^{\mathrm{a}}$ & $83 \pm 24^{\mathrm{a}}$ & $295 \pm 47$ \\
Plasma glucagon $(\mathrm{pg} / \mathrm{ml})$ & $49.4 \pm 3.5$ & $65.0 \pm 12.3$ & $58.3 \pm 4.2$ \\
Plasma epinephrine $(\mathrm{ng} / \mathrm{l})$ & $14.8 \pm 4.9$ & $17.2 \pm 8.3$ & $21.5 \pm 6.3$ \\
Plasma growth hormone $(\mathrm{ng} / \mathrm{ml})$ & $3.7 \pm 1.6$ & $2.1 \pm 1.0$ & $2.0 \pm 1.4$ \\
Energy expenditure $(\mathrm{kcal} / 24 \mathrm{~h})$ & $1,574 \pm 115$ & $1,815 \pm 187$ & $1,693 \pm 150$ \\
Respiratory exchange ratio & $0.802 \pm 0.015$ & $0.773 \pm 0.018$ & $0.811 \pm 0.010$ \\
\hline
\end{tabular}

${ }^{\mathrm{a}} p<0.05$ vs control subjects; ${ }^{\mathrm{b}} p<0.05$ vs insulin-treated state 
glucose averaged 5.0 and $5.6 \mathrm{mmol} / 1$ in the non-diabetic and insulin-treated subjects, respectively. It was elevated to $15.5 \mathrm{mmol} / \mathrm{l}$ in the diabetic subjects when they were insulin deprived. Plasma insulin averaged 4.4 and $10.8 \mathrm{mU} / 1$ in the non-diabetic and insulin-treated type 1 diabetic subjects and was decreased $(1.5 \mathrm{mU} / 1, p<0.05)$ in the insulindeprived type 1 diabetic subjects. No differences in circulating counter-regulatory hormones were detected. There was a non-significant trend towards elevated energy expenditure and a decreased respiratory exchange ratio during insulin deprivation $(0.10>p>0.05)$.

Phenylalanine and tyrosine dynamics

Whole body Circulating concentrations of phenylalanine and whole-body fluxes of phenylalanine and tyrosine (reflecting protein breakdown) were elevated during insulin deprivation $(p<0.05)$ (Table 2). The increase in phenylalanine flux was accompanied by a high rate of protein synthesis $(p<0.05)$, whereas phenylalanine to tyrosine conversion was unaffected.

Kidney In the basal state there was a small net uptake of phenylalanine of $\sim 2 \mu \mathrm{mol} / \mathrm{min}$ and a more pronounced net release of tyrosine of $\sim 5 \mu \mathrm{mol} / \mathrm{min}$ across the renal bed (Table 2). Renal appearance rates in plasma of $\left[{ }^{15} \mathrm{~N}\right]$ tyrosine originating from $\left[{ }^{15} \mathrm{~N}\right]$ phenylalanine (phenylalanine-to-tyrosine conversion) were close to $5 \mu \mathrm{mol} / \mathrm{min}$ in all cases. Renal phenylalanine and tyrosine dynamics were not altered by insulinopaenia.

Leg Phenylalanine appearance rates from protein (protein breakdown) were $5.4 \pm 0.6$ (control), $5.6 \pm 1.2$ (insulintreated) and $7.0 \pm 1.1$ (insulin-deprived) $\mu \mathrm{mol} / \mathrm{min}(p=0.07$ for insulin-treated vs insulin-deprived subjects) (Table 2). Local disappearance rates for phenylalanine (protein synthesis) were between 3.3 and $3.8 \mu \mathrm{mol} / \mathrm{min}$ in all cases $(p>0.05)$.

Table 2 Arterial plasma concentrations of amino acids and whole-body and renal phenylalanine and tyrosine fluxes in five diabetic subjects with and without insulin and in six control subjects

\begin{tabular}{|c|c|c|c|}
\hline & $\begin{array}{l}\text { Insulin-treated } \\
\text { diabetic patients }\end{array}$ & $\begin{array}{l}\text { Insulin-deprived } \\
\text { diabetic patients }\end{array}$ & Control subjects \\
\hline Phenylalanine $(\mu \mathrm{mol} / \mathrm{l})$ & $45.4 \pm 2.0^{\mathrm{a}}$ & $54.6 \pm 3.2^{\mathrm{b}}$ & $57.8 \pm 3.4$ \\
\hline Tyrosine $(\mu \mathrm{mol} / 1)$ & $39.3 \pm 5.7$ & $51.7 \pm 5.9$ & $51.3 \pm 4.9$ \\
\hline Phenylalanine flux $\left(\mu \mathrm{mol} \mathrm{kg}{ }^{-1} \mathrm{~h}^{-1}\right)$ & $32.6 \pm 1.0$ & $39.9 \pm 1.7^{\mathrm{b}}$ & $35.2 \pm 1.6$ \\
\hline Tyrosine flux ( $\left.\mu \mathrm{mol} \mathrm{kg}{ }^{-1} \mathrm{~h}^{-1}\right)$ & $25.8 \pm 1.1$ & $32.8 \pm 1.8^{\mathrm{b}}$ & $29.5 \pm 1.5$ \\
\hline Phenylalanine-to-tyrosine flux ( $\left.\mu \mathrm{mol} \mathrm{kg}{ }^{-1} \mathrm{~h}^{-1}\right)$ & $3.2 \pm 0.3$ & $3.6 \pm 0.3$ & $3.4 \pm 0.4$ \\
\hline Phenylalanine-to-protein flux $\left(\mu \mathrm{mol} \mathrm{kg}{ }^{-1} \mathrm{~h}^{-1}\right)$ & $29.5 \pm 1.0$ & $36.3 \pm 1.4^{\mathrm{b}}$ & $31.8 \pm 1.8$ \\
\hline Net phenylalanine organ balance $(\mu \mathrm{mol} / \mathrm{min})$ & $1.4 \pm 0.3$ & $2.2 \pm 0.9$ & $2.6 \pm 1.4$ \\
\hline Local renal phenylalanine rate of appearance $(\mu \mathrm{mol} / \mathrm{min})$ & $2.3 \pm 0.5$ & $1.8 \pm 0.5$ & $2.1 \pm 0.4$ \\
\hline Local organ phenylalanine rate of disappearance $(\mu \mathrm{mol} / \mathrm{min})$ & $3.6 \pm 0.7$ & $4.0 \pm 1.0$ & $4.7 \pm 1.3$ \\
\hline Net tyrosine organ balance $(\mu \mathrm{mol} / \mathrm{min})$ & $-5.9 \pm 1.1$ & $-4.7 \pm 0.7$ & $-5.2 \pm 1.6$ \\
\hline Local organ phenylalanine-to-tyrosine conversion ( $\mu \mathrm{mol} / \mathrm{min})$ & $4.6 \pm 0.8$ & $4.4 \pm 0.8$ & $5.2 \pm 1.3$ \\
\hline
\end{tabular}

Leucine dynamics

Whole body Total leucine C-flux representing protein breakdown was increased by $20 \%(p<0.05)$ by insulin deprivation (Table 3$)$. In parallel leucine oxidation was raised by $50 \%(p<0.05)$ and protein synthesis from leucine by $15 \%(p<0.05)$. Furthermore leucine-KIC interconversion was markedly increased in insulin-deprived subjects (KIC to leucine from 40 to $160 \mu \mathrm{mol} \mathrm{kg}^{-1} \mathrm{~h}^{-1}$ and leucine to KIC from 60 to $190 \mu \mathrm{mol} \mathrm{kg}^{-1} \mathrm{~h}^{-1}, p<0.05$ ).

Kidney Local leucine appearance from protein (protein breakdown) was between 3.7 and $5.7 \mu \mathrm{mol} / \mathrm{min}$ in all groups $(p>0.05)$ and disappearance rates (protein synthesis) were between 4.3 and $4.9 \mu \mathrm{mol} / \mathrm{min} \quad(p>0.05)$ (Table 3). Renal rates of leucine deamination were also stable $(8.1-11.9 \mu \mathrm{mol} / \mathrm{min})$ as were reamination rates $(6.2-10.2 \mu \mathrm{mol} / \mathrm{min})(p>0.05$ for all comparisons).

Leg Rates of protein breakdown and protein synthesis were comparable in all situations (Table 3 ), ranging from 7.5 to 12.8 and 6.1 to $6.8 \mu \mathrm{mol} / \mathrm{min}$, respectively $(p>0.05)$. Compared with the insulin-treated state rates of leucine reamination and deamination were both doubled during insulin deprivation (52 vs 26 and 55 vs $25 \mu \mathrm{mol} / \mathrm{min}$, $p<0,05)$; compared with control subjects $p=0.08$ and $p=0.07$ for reamination and deamination during insulinopaenia, respectively.

\section{Glucose dynamics}

During insulin deprivation glucose appearance rates increased approximately two-fold $(p<0.05)$ (Table 4). Concomitantly there was a trend towards increased renal glucose uptake $(p>0.05)$, while renal glucose production remained unaffected $(p>0.05)$. Renal glucose production rates remained low with a high variation between subjects. This variation was primarily the result of highly variable dilution of deuterated glucose across the kidney, ranging

${ }^{\mathrm{a}} p<0.05$ vs control subjects; ${ }^{\mathrm{b}} p<0.05$ vs insulin-treated state 
Table 3 Whole-body and renal and leg dynamics of leucine in five diabetic subjects with and without insulin and in six control subjects

\begin{tabular}{lccc}
\hline & Insulin-treated diabetic patients & Insulin-deprived diabetic patients & Control subjects \\
\hline Leucine C-flux $\left(\mu \mathrm{mol} \mathrm{kg} \mathrm{k}^{-1}\right)$ & $99.6 \pm 2.1^{\mathrm{a}}$ & $120.8 \pm 3.8^{\mathrm{b}}$ & $116.8 \pm 5.9$ \\
Leucine oxidation $\left(\mu \mathrm{mol} \mathrm{kg}^{-1} \mathrm{~h}^{-1}\right)$ & $20.6 \pm 2.1$ & $31.9 \pm 4.7^{\mathrm{b}}$ & $22.5 \pm 2.0$ \\
Leucine to protein $\left(\mu \mathrm{mol} \mathrm{kg}^{-1} \mathrm{~h}^{-1}\right)$ & $79.0 \pm 3.4^{\mathrm{a}}$ & $88.9 \pm 5.9^{\mathrm{b}}$ & $94.3 \pm 3.9$ \\
Leucine N-flux $\left(\mu \mathrm{mol} \mathrm{kg} \mathrm{h}^{-1}\right)$ & $139 \pm 126$ & $278 \pm 24^{\mathrm{a}, \mathrm{b}}$ & $167 \pm 7$ \\
KIC to leucine $\left(\mu \mathrm{mol} \mathrm{kg} \mathrm{h}^{-1}\right)$ & $39 \pm 11$ & $157 \pm 21^{\mathrm{a}, \mathrm{b}}$ & $51 \pm 5$ \\
Leucine to KIC $\left(\mu \mathrm{mol} \mathrm{kg} \mathrm{h}^{-1}\right)$ & $60 \pm 9$ & $189 \pm 24^{\mathrm{a}, \mathrm{b}}$ & $73 \pm 5$ \\
Net renal leucine balance $(\mu \mathrm{mol} / \mathrm{min})$ & $1.1 \pm 2.2$ & $0.5 \pm 1.1$ & $2.0 \pm 0.8$ \\
Net renal KIC balance $(\mu \mathrm{mol} / \mathrm{min})$ & $2.4 \pm 0.5$ & $4.0 \pm 2.9$ & $4.9 \pm 3.6$ \\
Renal leucine protein breakdown $(\mu \mathrm{mol} / \mathrm{min})$ & $5.7 \pm 0.8$ & $13.4 \pm 2.9$ & $5.5 \pm 1.1$ \\
Renal leucine protein synthesis $(\mu \mathrm{mol} / \mathrm{min})$ & $4.8 \pm 2.3$ & $5.4 \pm 2.7$ & $3.7 \pm 2.4$ \\
Across-kidney leucine N flux $(\mu \mathrm{mol} / \mathrm{min})$ & $11.9 \pm 1.6$ & $9.0 \pm 2.7$ & $4.3 \pm 3.7$ \\
Across-kidney leucine C flux $(\mu \mathrm{mol} / \mathrm{min})$ & $6.8 \pm 0.9$ & $8.5 \pm 3.1$ & $13.8 \pm 2.4$ \\
Across-kidney leucine reamination $(\mu \mathrm{mol} / \mathrm{min})$ & $6.2 \pm 1.1$ & $12.8 \pm 2.1$ & $5.9 \pm 2.3$ \\
Across-kidney leucine deamination $(\mu \mathrm{mol} / \mathrm{min})$ & $8.2 \pm 1.6$ & $6.1 \pm 2.7$ & $10.2 \pm 1.9$ \\
Across-leg leucine protein breakdown $(\mu \mathrm{mol} / \mathrm{min})$ & $10.0 \pm 2.0$ & $52.0 \pm 9.7^{\mathrm{a}, \mathrm{b}}$ & $11.9 \pm 2.5$ \\
Across-leg protein synthesis $(\mu \mathrm{mol} / \mathrm{min})$ & $6.5 \pm 3.0$ & $55.2 \pm 10.7^{\mathrm{a}, \mathrm{b}}$ & $7.5 \pm 1.1$ \\
Across-leg leucine reamination $(\mu \mathrm{mol} / \mathrm{min})$ & $26.1 \pm 6.2$ & & $6.8 \pm 1.5$ \\
Across leg leucine deamination $(\mu \mathrm{mol} / \mathrm{min})$ & $28.3 \pm 6.3$ & & $29.1 \pm 3.7$ \\
\hline
\end{tabular}

${ }^{\mathrm{a}} p<0.05$ vs controls; ${ }^{\mathrm{b}} p<0.05$ vs insulin-treated state

from 11.8 to $-9.5 \%$ (mean of five measurements) in each individual. The renal contribution to total body endogenous glucose production during insulin deprivation decreased slightly, but not significantly, from $\sim 15$ to $7 \%$.

\section{NEFA dynamics}

Under conditions of insulin deprivation circulating palmitate concentrations and whole-body appearance rates were more than doubled and there was a trend towards increased femoral release of palmitate, although this was not statistically significant (Table 5). Regardless of conditions, kidney exchange of palmitate was close to zero. When deprived of insulin, subjects tended to exhibit increased palmitate concentrations, appearance rates and femoral release and uptake rates (all $p$ values between 0.06 and 0.2 ). It could be argued that the comparisons between insulin-deprived and insulin-replaced values should be one-sided because we know the direction of change.

\section{Discussion}

The current study was conducted to define the role of the kidney in amino acid, fat and glucose metabolism in nondiabetic and insulin-treated type 1 diabetic subjects and to identify renal components that contribute to the metabolic derangement caused by acute insulinopaenia in type 1 diabetic subjects. Our main findings are that in the basal state $5-10 \%$ of whole-body protein flux, close to $20 \%$ of leucine-KIC interconversion and a major part of phenylalanine-to-tyrosine conversion occur in kidney. During acute insulin withdrawal the leg becomes a major site for leucine transamination, whereas local renal phenylalanine, leucine and glucose kinetics remained unaffected. Of note, the diabetic subjects studied were not insulin deficient for a long time; although fasting plasma glucose levels were above $15 \mathrm{mmol} / \mathrm{l}, 3$-hydroxybutyrate concentrations were only modestly raised at $1.6 \mathrm{mmol} / \mathrm{l}$, and it is conceivable that more prolonged insulin deficiency might have affected the outcome of the study. On the other hand, the insulinopaenia imposed under the present experimental

Table 4 Whole-body appearance rates for glucose and renal net glucose balances, and glucose appearance and disappearance rates in five diabetic subjects with and without insulin and in six control subjects

\begin{tabular}{llcc}
\hline & Insulin-treated diabetic patients & Insulin-deprived diabetic patients & Control subjects \\
\hline Glucose rate of appearance $\left(\mathrm{mg} \mathrm{kg}^{-1} \mathrm{~min}^{-1}\right)$ & $1.89 \pm 0.08$ & $4.43 \pm 0.43^{\mathrm{a}, \mathrm{b}}$ & $1.98 \pm 0.10$ \\
$(\mu \mathrm{mol} / \mathrm{min})$ & $(747 \pm 58)$ & $(1751 \pm 353)^{\mathrm{a}, \mathrm{b}}$ & $(830 \pm 75)$ \\
Net renal glucose balance $(\mu \mathrm{mol} / \mathrm{min})$ & $-26 \pm 3$ & $202 \pm 23$ & $-39 \pm 3$ \\
Renal glucose production $(\mu \mathrm{mol} / \mathrm{min})$ & $103 \pm 50$ & $130 \pm 214$ & $138 \pm 133$ \\
Renal $\left[6,6-{ }^{2} \mathrm{H}_{2}\right]$ glucose dilution $(\%)$ & $1.34 \pm 0.86$ & $-0.28 \pm 2.39$ & $2.48 \pm 2.12$ \\
Renal glucose uptake $(\mu \mathrm{mol} / \mathrm{min})$ & $78 \pm 77$ & $332 \pm 360$ & $99 \pm 128$ \\
\hline
\end{tabular}

${ }^{\mathrm{a}} p<0.05$ vs controls; ${ }^{\mathrm{b}} p<0.05$ vs insulin-treated state 
Table 5 Arterial plasma concentrations and whole-body appearance rates for palmitate and femoral and renal net palmitate balances, and palmitate release and uptake rates in five diabetic subjects with and without insulin and in six control subjects

\begin{tabular}{lccc}
\hline & Insulin-treated diabetic patients & Insulin-deprived diabetic patients & Control subjects \\
\hline Palmitate concentration $(\mu \mathrm{mol} / \mathrm{l})$ & $95 \pm 34$ & $246 \pm 46^{\mathrm{a}}$ & $122 \pm 9$ \\
Palmitate rate of appearance $(\mu \mathrm{mol} / \mathrm{min})$ & $97 \pm 25$ & $265 \pm 71$ & $132 \pm 18$ \\
Net femoral palmitate balance $(\mu \mathrm{mol} / \mathrm{min})$ & $-5.3 \pm 1.1$ & $-7.5 \pm 2.0$ & $-2.2 \pm 0.8$ \\
Femoral palmitate release $(\mu \mathrm{mol} / \mathrm{min})$ & $18.9 \pm 1.9$ & $31.3 \pm 4.4$ & $20.2 \pm 6.7$ \\
Femoral palmitate uptake $(\mu \mathrm{mol} / \mathrm{min})$ & $13.6 \pm 2.1$ & $23.8 \pm 5.4$ & $17.8 \pm 5.2$ \\
Net renal palmitate balance $(\mu \mathrm{mol} / \mathrm{min})$ & $5.5 \pm 2.6$ & $7.3 \pm 3.7$ & $5.4 \pm 1.7$ \\
Renal palmitate release $(\mu \mathrm{mol} / \mathrm{min})$ & $-0.4 \pm 2.6$ & $-10.0 \pm 4.6$ & $0.5 \pm 1.9$ \\
Renal palmitate uptake $(\mu \mathrm{mol} / \mathrm{min})$ & $5.1 \pm 3.7$ & $-2.8 \pm 1.9$ & $5.9 \pm 2.2$ \\
\hline$p<0.05$ con
\end{tabular}

${ }^{\mathrm{a}} p<0.05$ vs control subjects

conditions did not increase circulating levels of any of the counterregulatory hormones, this allowed assessment of insulin per se without interference from other metabolic hormones.

It is well recognised that insulin is a protein anabolic hormone. In untreated type 1 diabetes prolonged lack of insulin leads to cachexia, excessive urinary nitrogen loss and decreased lean body mass, all of which revert to normal upon insulin therapy [25-27]. In accordance with previous studies $[2,3]$ we found that insulin deprivation increases whole-body protein breakdown, as evidenced by increased flux rates of phenylalanine, tyrosine and leucine of around $20 \%$. This effect is to some extent offset by a concomitant increase in protein synthesis, which could relate to increased levels of circulating amino acids. In addition, uncontrolled diabetes is characterised by dramatic three- to five-fold increases of leucine-KIC transamination rates, as also observed in the present study [3]. Theoretically this biochemical reaction could provide a mechanism for the transfer of surplus nitrogen from gluconeogenic precursors such as glutamine. The tissues behind these metabolic aberrations have not been precisely defined in previous studies [3], although it has been shown that both splanchnic and leg tissues contribute to increased protein breakdown. The present study adds new evidence that the leg is a primary site for leucine transamination - the doubling of both leucine deamination and reamination rates observed across the leg accounts for the majority of the three- to four-fold increase of leucine transamination at the wholebody level.

Our observations do not support the premise that the kidney plays any major role during insulin withdrawal on protein metabolism. The finding that $5-10 \%$ of wholebody phenylalanine and leucine fluxes occur across the renal bed is in line with a previous study [13], which reported a renal component of $10 \%$ in patients with hypertension and cardiac disease. In addition, our data demonstrated that the kidney participates in leucine transamination; in all three groups studied reamination and deamination rates consistently ranged from 6 to $12 \mu \mathrm{mol} / \mathrm{min}$, corresponding to between 10 and $20 \%$ of whole-body transamination under conditions of wellcontrolled insulin. These findings are in contrast to the previous study [13], which reported renal transamination rates below zero. The discrepancy could relate to the different patient categories studied, because it cannot be excluded that patients with hypertension and cardiac disease may have subtly compromised renal function. Finally, we confirm our recent observation that the kidney is an important site for phenylalanine-to-tyrosine conversion [14], by showing that this also applies to diabetic subjects, in whom we observed renal conversion rates of around $5 \mu \mathrm{mol} / \mathrm{min}$, regardless of whether insulin was administered. This indicates that the kidney's key role as a supplier of tyrosine to the systemic circulation during the postabsorptive state is unaffected by insulin deficiency and the associated metabolic derangements. In addition, these data indicate that kidney does not contribute actively to the altered metabolic conditions associated with insulin deficiency.

The renal contribution to endogenous glucose production has been a matter of much controversy $[4-12,28]$. Much of the confusion in all likelihood has arisen from the fact that measurements across the renal bed, because of the high renal blood flow of around $11 / \mathrm{min}$, are highly susceptible to methodological imprecision as regards analysis of differences in arteriovenous glucose concentrations and dilution of tracers. In general, the observed differences are close to the detection limits of the assays employed. In the present study we found average renal glucose production rates of $100-140 \mu \mathrm{mol} / \mathrm{min}$, amounting to around $15 \%$ of endogenous glucose production. There was, however, huge interindividual variation. This picture is in agreement with the literature, where production rates between 0 and $30 \%$ have been reported [28]. Previous studies have reported that high levels of insulin may suppress renal glucose production in healthy control subjects $[6,11]$. We failed to observe any effect of acute insulin deficiency on renal glucose production in type 1 diabetic subjects, but as noted above it is possible that more severe hypoinsulinaemia could have promoted renal glucose production. In particular, it should be noticed that under the current conditions insulin withdrawal did not augment circulating epinephrine concentrations and that epinephrine has been reported to stimulate renal glucose production; and blood levels of epinephrine increase in severe diabetic derangement, such as ketoacidosis $[4,6]$. 
Enhanced lipolysis and uncontrolled ketogenesis following insulin deprivation can lead to diabetic ketoacidosis. Our results suggest that moderate hypoinsulinaemia increases appearance rates and circulating concentrations of NEFA and that adipose tissue in the leg contributes by releasing high amounts of NEFA. Only very few studies have examined renal free fatty acid metabolism in humans $[15,16,29]$. One of these studies reported a substantial renal uptake of NEFA [15], whereas another failed to confirm this observation [16]. More recently Jensen et al. reported a total NEFA uptake in the kidney of $26 \mu \mathrm{mol} / \mathrm{min}$ in 60-h-fasted subjects [30]. The present findings suggest that the kidney plays a minor role in NEFA metabolism

In summary, we find that in the postabsorptive state the kidney contribute $5-10 \%$ of whole-body protein turnover, $15-20 \%$ of leucine transamination, $15 \%$ of endogenous glucose production and that the kidney actively converts phenylalanine to tyrosine. Acute insulin withdrawal has no detectable effect on these parameters, albeit the leg becomes a major site for leucine reamination and deamination.

Acknowledgements We thank the nursing and dietetic staff of Mayo General Clinical Research Center. We are grateful for the skilful technical assistance of C. Ford, M. Persson, J. Kahl, D. Morse and J. Schimke, and for assistance in the conduct of the study by M. Bigelow. The study is supported by National Institutes of Health grants RO1 DK41973 and MO1 RR00585 and Mayo Foundation. K. S. Nair is David Murdock-Dole Professor of Nutrition at the Mayo Clinic.

Duality of interest The authors declare that they have no conflicts of interest as regards this study.

\section{References}

1. Miles JM, Rizza RA, Haymond MW, Gerich J (1980) Effects of acute insulin deficiency on glucose and ketone body turnover in man. Evidence for the primacy of overproduction of glucose and ketone bodies in the genesis of diabetic ketoacidosis. Diabetes 29:926-930

2. Nair KS, Garrow JS, Ford C, Mahler RF, Halliday D (1983) Effect of poor diabetic control and obesity on whole body protein metabolism in man. Diabetologia 25:400-403

3. Nair KS, Ford GC, Ekberg K, Fernqvist-Forbes E, Wahren J (1995) Protein dynamics in whole body and in splanchnic and leg tissues in type I diabetic patients. J Clin Invest 95:2926-2937

4. Stumvoll M, Meyer C, Mitrakou A, Nadkarni V, Gerich JE (1997) Renal glucose production and utilization: new aspects in humans. Diabetologia 40:749-757

5. Cersosimo E, Judd RL, Miles JM (1994) Insulin regulation of renal glucose metabolism in conscious dogs. J Clin Invest 93:2584-2589

6. Stumvoll M, Chintalapudi U, Perriello G, Welle SL, Gutierrez O, Gerich JE (1995) Uptake and release of glucose by the human kidney. Postabsorptive rates and responses to epinephrine. J Clin Invest 96:2528-2533

7. Stumvoll M, Meyer C, Perriello G, Kreider M, Welle S, Gerich J (1998) Human kidney and liver gluconeogenesis: evidence for organ substrate selectivity. Am J Physiol 274:E817-E826
8. Stumvoll M, Meyer C, Kreider M, Perriello G, Gerich J (1998) Effects of glucagon on renal and hepatic glutamine gluconeogenesis in normal postabsorptive humans. Metabolism 47:1227-1232

9. Meyer C, Stumvoll M, Nadkarni V, Dostou J, Mitrakou A, Gerich J (1998) Abnormal renal and hepatic glucose metabolism in type 2 diabetes mellitus. J Clin Invest 102:619-624

10. Cersosimo E, Garlick P, Ferretti J (1999) Insulin regulation of renal glucose metabolism in humans. Am J Physiol 276 : E78-E84

11. Cersosimo E, Garlick P, Ferretti J (1999) Renal glucose production during insulin-induced hypoglycemia in humans. Diabetes 48:261-266

12. Ekberg K, Landau BR, Wajngot A et al (1999) Contributions by kidney and liver to glucose production in the postabsorptive state and after $60 \mathrm{~h}$ of fasting. Diabetes 48:292-298

13. Tessari P, Garibotto G, Inchiostro S et al (1996) Kidney, splanchnic, and leg protein turnover in humans: insight from phenylalanine kinetics. J Clin Invest 98:1481-1492

14. Moller N, Meek S, Bigelow M, Andrews J, Nair KS (2000) The kidney is an important site for in vivo phenylalanine-to-tyrosine conversion in adult humans: a metabolic role of the kidney. Proc Natl Acad Sci USA 97:1242-1246

15. Nieth H, Schollmeyer P (1966) Substrate utilization of the human kidney. Nature 209:1244-1245

16. Wahren J, Felig P (1975) Renal substrate exchange in human diabetes mellitus. Diabetes 24:730-734

17. Brundin T, Wahren J (1994) Renal oxygen consumption, thermogenesis, and amino acid utilization during i.v. infusion of amino acids in man. Am J Physiol 267:E648-E655

18. Charlton MR, Adey DB, Nair KS (1996) Evidence for a catabolic role of glucagon during an amino acid load. J Clin Invest 98:90-99

19. Krury D, Keller U (1991) Trimethylsilyl-O-derivatives for the measurement of $\left[6,6-{ }^{2} \mathrm{H}_{2}\right]$-D-glucose-enriched plasma samples by gas chromatography-mass spectrometry. J Chromatogr Appl 572:302-306

20. Jensen MD, Rogers PJ, Ellman MG, Miles JM (1988) Choice of infusion-sampling mode for tracer studies of free fatty acid metabolism. Am J Physiol 254:E562-E656

21. Thompson GN, Pacy PJ, Merritt H et al (1989) Rapid measurement of whole body and forearm protein turnover using a $\left[{ }^{2} \mathrm{H}_{5}\right]$ phenylalanine model. Am J Physiol 256:E631-E639

22. Cheng KN, Dworzak F, Ford GC, Rennie MJ, Halliday D (1985) Direct determination of leucine metabolism and protein breakdown in humans using $\mathrm{L}-\left(1-{ }^{13} \mathrm{C},{ }^{15} \mathrm{~N}\right)$ leucine and forearm model. Eur J Clin Invest 15:345-353

23. Wolfe RR (1992) Radioactive and stable isotopes tracers in biomedicine. In: Principles and Practice of Kinetic Analysis. Wiley-Liss, New York p. 186

24. Jensen MD, Cryer PE, Johnson CM, Murray MJ (1996) Effects of epinephrine on regional free fatty acid and energy metabolism in men and women. Am J Physiol 270:E259-E264

25. Geyelin HR, Harrop G, Murray MF, Corwin E (1922) The use of insulin in juvenile diabetes. J Metab Res 11:767-791

26. Atchley DW, Loeb RF, Richards DW Jr, Benedict EIM, Driscoll ME (1933) On diabetic acidosis - a detailed study of electrolyte balances following the withdrawal and reestablishment of insulin therapy. J Clin Invest 12:297-326

27. Walsh CH, Soler NG, James H et al (1976) Studies in whole body potassium and whole body nitrogen in newly diagnosed diabetics. Q J Med 45:295-301

28. Moller N, Rizza RA, Ford GC, Nair KS (2001) Assessment of postabsorptive renal glucose metabolism in humans with multiple glucose tracers. Diabetes 50:747-751

29. Hillier TA, Pedula KL (2001) Characteristics of an adult population with newly diagnosed type 2 diabetes. Diabetes Care 24:1522-1527

30. Jensen MD, Ekberg K, Landau BR (2001) Lipid metabolism during fasting. Am J Physiol-Endocrinol Metab 281:E789-E793 